\title{
Studies on quality evaluation of blanched turmeric
}

\author{
S.P. KuRheKAR*, S.R. PATIL And R.R. PATIL ${ }^{1}$
}

Department of Farm Structures, College of Agricultural Engineering and Technology, Dr. Balasaheb Sawant Konkan Krishi Vidyapeeth, Dapoli, RATNAGIRI (M.S.) INDIA

${ }^{1}$ Karunya University, Karunya Nagar, COIMBATORE (T.N.) INDIA

*Author for Correspondence

Research chronicle : Received : 27.08.2014; Revised : 13.05.2015; Accepted : 28.05.2015

\section{SUMMARY :}

Turmeric is one of the important cash crops. The area under turmeric cultivation is increasing day by day but its processing is done by traditional method leading to loss of fuel, time and quality. Processing of turmeric assumes importance from of appearance and colour point of view. The processing of turmeric by blanching was compared to the conventional method of boiling the rhizomes. It was observed that the average length, breadth and thickness of fresh turmeric rhizomes was 71.29, 25.19 and $24.08 \mathrm{~mm}$ whereas that of blanched turmeric rhizomes, it was 69.72, 24.42 and $22.99 \mathrm{~mm}$, respectively. The average values of weight, volume, and true density of fresh and blanched single turmeric rhizome were observed $26.86 \mathrm{~g}, 26.15 \mathrm{~cm}^{3}, 1.026 \mathrm{~g} / \mathrm{cm}^{3}$ and $25.62 \mathrm{~g}, 24.23 \mathrm{~cm}^{3}, 1.07 \mathrm{~g} / \mathrm{cm}^{3}$, respectively. The skin removal and stick piercing in turmeric rhizomes blanched for 25,30 and 35 minutes is less easy, easy and more easy, respectively. The turmeric rhizomes blanched and boiled for 25,30 and 35 minute retains curcumin content 4.27 per cent, 4.09 per cent, 4.01 per cent and 4.21 per cent, 3.91 per cent, 2.29 per cent, respectively.

KEY WORDS : Turmeric, Blanching, Turmeric processing

How to cite this paper : Kurhekar, S.P., Patil, S.R. and Patil, R.R. (2015). Studies on quality evaluation of blanched turmeric. Internat. J. Proc. \& Post Harvest Technol., 6 (1) : 114-117. 